\title{
Pediatric Neutropenic Patients Care in Turkey
}

\author{
Türkiye' de Pediatrik Nötropenik Hasta İlemi
}

Zeynep Gökçe Gayretli Aydın'(iD), Ayşe Büyükcam²(iD), Ateş Kara²(iD), Adem Karbuz(iD), Ahmet Soysal'(iD),

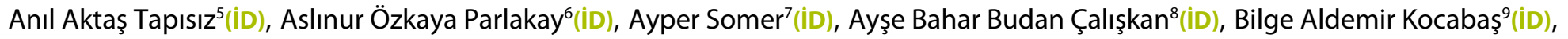
Dicle Şener Okur ${ }^{10}(\mathrm{ID})$, Dilek Yılmaz Çiftdoğan ${ }^{11}(\overline{1})$

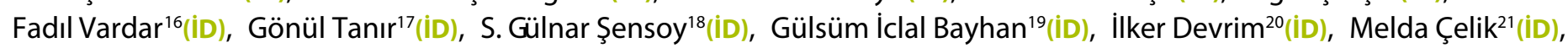

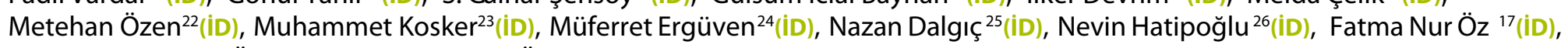
Nurşen Belet ${ }^{21}(\overline{1})$

Serdar Özkasap ${ }^{31},(\bar{D})$, , Solmaz Çelebi ${ }^{32}(\overline{1})$

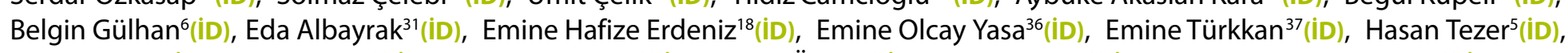

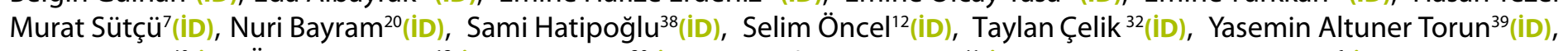

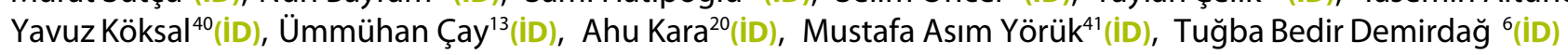

${ }^{1}$ Division of Pediatric Infectious Diseases, Department of Pediatrics, Karadeniz Technical University School of Medicine, Trabzon, Turkey

${ }^{2}$ Division of Pediatric Infectious Diseases, Department of Pediatrics, Hacettepe University School of Medicine, Ankara, Turkey

${ }^{3}$ Clinic of Pediatric Infectious Diseases, Istanbul Okmeydani Training and Research Hospital, Istanbul, Turkey

${ }^{4}$ Division of Pediatric Infectious Diseases, Department of Pediatrics, Marmara University School of Medicine, Istanbul, Turkey

${ }^{5}$ Division of Pediatric Infectious Diseases, Department of Pediatrics, Gazi University School of Medicine, Ankara, Turkey

${ }^{6}$ Clinic of Pediatric Infectious Diseases, Ankara Pediatrics Hematology Oncology Training and Research Hospital, Ankara, Turkey

${ }^{7}$ Division of Pediatric Infectious Diseases, Department of Pediatrics, Istanbul University School of Medicine, Istanbul, Turkey

${ }^{8}$ Clinic of Pediatric Infectious Diseases, Istanbul Haseki Training and Research Hospital, Istanbul, Turkey

${ }^{9}$ Clinic of Pediatric Infectious Diseases, Antalya Training and Research Hospital, Antalya,

${ }^{10}$ Clinic of Pediatric Infectious Diseases, Denizli State Hospital, Denizli, Turkey

${ }^{11}$ Clinic of Pediatric Infectious Diseases, Izmir Tepecik Training and Research Hospital, Istanbul, Turkey

${ }^{12}$ Division of Pediatric Infectious Diseases, Department of Pediatrics, Kocaeli University School of Medicine, Kocaeli, Turkey

${ }^{13}$ Division of Pediatric Infectious Diseases, Department of Pediatrics, Cukurova University School of Medicine, Adana, Turkey

${ }^{14}$ Division of Pediatric Infectious Diseases, Department of Pediatrics, Ankara University School of Medicine, Ankara, Turkey

${ }^{15}$ Division of Pediatric Hematology and Oncology, Department of Pediatrics, Karadeniz Technical University School of Medicine, Istanbul, Turkey

${ }^{16}$ Division of Pediatric Infectious Diseases, Department of Pediatrics, Ege University School of Medicine, Izmir, Turkey

${ }^{17}$ Clinic of Pediatric Infectious Diseases, Ankara Dr. Sami Ulus Maternity and Child Health and Diseases Training and Research Hospital, Ankara, Turkey

${ }^{18}$ Division of Pediatric Infectious Diseases, Department of Pediatrics, Ondokuz Mayis University School of Medicine, Samsun, Turkey

${ }^{19}$ Division of Pediatric Infectious Diseases, Department of Pediatrics, Yildirim Beyazit University School of Medicine, Ankara, Turkey

${ }^{20}$ Clinic of Pediatric Infectious Diseases, Dr. Behcet Uz Child Diseases Training and Research Hospital, Izmir, Turkey

${ }^{21}$ Clinic of Pediatric Infectious Diseases, Ankara Kecioren Training and Research Hospital, Ankara, Turkey

${ }_{22}$ Division of Pediatric Infectious Diseases, Department of Pediatrics, Acibadem University School of Medicine, Istanbul, Turkey

${ }^{23}$ Clinic of Pediatric Infectious Diseases, Diyarbakir Region Training and Research Hospital, Diyarbakir, Turkey

${ }^{24}$ Department of Pediatrics, Istanbul Medeniyet University School of Medicine, Istanbul, Turkey

${ }^{25}$ Clinic of Pediatric Infectious Diseases, Sisli Hamidiye Training and Research Hospital, Istanbul, Turkey

${ }^{26}$ Clinic of Pediatric Infectious Diseases, Istanbul Kanuni Sultan Suleyman Training and Research Hospital, Istanbul, Turkey

${ }^{27}$ Division of Pediatric Infectious Diseases, Department of Pediatrics, Dokuz Eylul University School of Medicine, Izmir, Turkey

${ }^{28}$ Clinic of Pediatric Infectious Diseases, Konya Training and Research Hospital, Konya, Turkey

${ }^{29}$ Clinic of Pediatric Infectious Diseases, Sivas State Hospital, Sivas, Turkey

${ }^{30}$ Clinic of Pediatric Infectious Diseases, Kayseri Training and Research Hospital, Kayseri, Turkey

${ }^{31}$ Department of Pediatrics, Recep Tayyip Erdogan University School of Medicine, Rize, Turkey

\section{Correspondence Address/Yazışma Adresi \\ Zeynep Gökçe Gayretli Aydın \\ Karadeniz Teknik Üniversitesi Tıp Fakültesi, \\ Çocuk Enfeksiyon Hastalıkları Bilim Dalı, \\ Trabzon-Türkiye \\ E-mail: zggayretli@gmail.com}

Received: 03.04.2019 
Gayretli Aydın et al.

${ }^{32}$ Division of Pediatric Infectious Diseases, Department of Pediatrics, Uludag University School of Medicine, Bursa, Turkey

${ }^{33}$ Clinic of Pediatric Infectious Diseases, Adana Numune Training and Research Hospital, Adana, Turkey

${ }^{34}$ Division of Pediatric Infectious Diseases, Department of Pediatrics, Istanbul University School of Cerrahpasa Medicine, Istanbul, Turkey

${ }^{35}$ Clinic of Pediatric Hematology Oncology, Adana Numune Training and Research Hospital, Adana, Turkey

${ }^{36}$ Clinic of Pediatrics, Medeniyet University Goztepe Training and Research Hospital, Istanbul, Turkey

${ }^{37}$ Clinic of Pediatric Hematology, Istanbul Okmeydani Training and Research Hospital, Istanbul, Turkey

${ }^{38}$ Clinic of Pediatric Infectious Diseases, Istanbul Bakirkoy Dr. Sadi Konuk Training and Research Hospital, Istanbul, Turkey

${ }^{39}$ Clinic of Pediatric Oncology, Kayseri Training and Research Hospital, Kayseri, Turkey

${ }^{40}$ Department of Pediatrics, Selcuk University School of Meram Medicine, Konya, Turkey

${ }^{41}$ Division of Pediatric Oncology, Department of Pediatrics, Istanbul Medeniyet University School of Medicine, Istanbul, Turkey

Cite this article as: Gayretli Aydın ZG, Büyükcam A, Kara A, Karbuz A, Soysal A, Aktaş Tapısız A, et al. Epidemiology of sepsis in neonates: microbiological profile and antibiotic susceptibility. J Pediatr Inf 2019;13(4):e141-e146.

Abstract

Objective: Infection is a common complication in children with malignancies. There is no consistent guidance for environmental infection control and isolation precautions for neutropenic patients (NP). There are differences between centers. The aim of this questionnaire study was to determine these differences in Turkey.

Material and Methods: A multicenter-descriptive questionnaire was conducted on 36 centers from different geografical locations of Turkey. Bone marrow transplantation units were excluded. Each center was contacted at least three-times. Questionnaire was answered by two different doctors from each center.

Results: Thirty-six centers including 20 (55.5\%) University Hospitals, 12 (\%33.3) Research Hospitals, three (8.3\%) State Hospital and one Private University Hospital participated in this survey. $94.3 \%$ of the centers had a bed capacity of 50 beds and over. Twenty-one (58.3\%) centers had pediatric infection ward that followed febrile NP. All centers had an infection control committee. $25 \%$ (9/36) of the centers always followed pediatric neutropenic fever patients in a single room. $66.6 \%(24 / 36)$ of the centers had toilet in all patients' room. The door features of patients' room included mostly $(94.1 \%, 32 / 34)$ manually opened door. Ten $(27.7 \%)$ centers had hepa filter system, five of them had positive-negative pressure room. Thirteen $(38.2 \%, 13 / 34)$ centers prefered hickmann catheter for accessing a patient's central line. Training was given for catheteter care in all centers. Sixteen (44.4\%) centers had determined policies about keeping toys in patient rooms. Visitor restrictions were performed in all centers. None of the centers allowed plants or flowers in hospital rooms. There was a neutropenic diet specific for pediatric NP provided in twenty-seven centers (75\%).

Conclusion: The prevention and control of infection contributes to the improvement of the prognosis of patients with hematological malignancies. Physicians must be aware of the infection risks and take precautions for infectious complications through the neutropenic period and standard protocols should be established and implemented for patients with hematological malignancies.

Keywords: Neutropenic patients, children, infection control

\section{Introduction}

Infections are major causes of morbidity and mortality in children with cancers, especially during periods of neutropenia (1). Sources of infections could be both community acquired and health care associated. The sources of community acquired infections in neutropenic children are usually their
Öz

Giriş: Maligniteli hastaların tedavi sürecindeki en önemli komplikasyonlardan biri enfeksiyonlardır. Nötropenik hastalarda enfeksiyon kontrolü ve izolasyon önlemleri için merkezden merkeze değişen farklı uygulamalar mevcuttur. Anket çalışmasının amacı Türkiye'deki bu farklılıkları ve ihtiyaçları belirlemektir.

Gereç ve Yöntemler: Çok merkezli tanımlayıcı çalışmaya Türkiye'nin farklı coğrafik bölgelerinden pediatrik nötropenik hasta takip eden 36 merkez dahil edildi. Kemik iliği transplantasyon üniteleri çalışmaya alınmadı. Her merkezle en az üç kez iletişime geçildi. Anketi her merkezden iki doktor yanıtladı. Anket kişisel, genel hasta bakımı ve nötropenik hasta bakımını içeren 64 sorudan oluşmaktaydı.

Bulgular: Çalışmaya katılan merkezlerin 20 (\%55.5)'si üniversite hastanesi, 12 (\%33.3)'si eğitim araştırma hastanesi, 3 (\%8.3)'ü devlet hastanesi ve bir tanesi de özel üniversite hastanesi idi. Merkezlerin \%94.3'ünün yatak kapasitesi 50 yatak ve üzerinde idi. Yirmi bir (\%58) merkezin çocuk enfeksiyon hastalıkları servisi mevcuttu. Tüm merkezlerin enfeksiyon kontrol komitesi vardı. Merkezlerin \%25 $(n=9)$ 'inde nötropenik ateş (NPA) tanısı alan çocuk hastalar tek kişilik odalarda izleniyordu. Tüm odalarda tuvalet bulunan merkez sayısı 24 (\%66.6) idi. Hasta odalarının büyük çoğunluğunda elle açılıp kapanır kapı (\%94.1) ve musluk (\%97.1) mevcuttu. On (\%27.7) merkezin oda havalandırması için hepa-filtreli sistemi vardı. Beşinde negatif basınçlı oda mevcuttu. On üç merkezde kateter olarak hickman kateter tercih edilmişti. Tüm merkezlerde kateter bakımı için eğitim verilmekte idi. Hiçbir merkezde hasta ziyaretine ve hastane odasında bitki veya çiçek bulundurmaya izin verilmemekteydi. Merkezlerin \%45.7'sinde hastanede oyuncak bulundurma ile ilgili hastane politikası vardı.

Sonuç: Sonuç olarak, nötropenik hastaları enfeksiyondan korumak için hastanelerde çeşitli yaklaşımlar uygulanmaktadır. Rehberler belirlenip bu rehberler ışığında hastane koşulları düzenlenmeli ve nötropenik hasta izlemi yapılmalıdır.

Anahtar Kelimeler: Nötropenik hastalar, çocuk, enfeksiyon kontrolü

own microbiota, and sometimes enviroment and relatives. The sources of healthcare associated infection in neutropenic children are also their own microbiota, hospital enviroment, health care workers $(\mathrm{HCW})$, other patients, their relatives, medical procedures and device associated. With advances in aggressive treatment modalities, including transplantation and multimodality regimens for underlying diseases, survival 
rate has improved greatly among patients with hematological malignancies. Beside these effective treatments, the most effective way to reduce mortality is infection prevention and control (2). Therefore, personal and hand hygiene, hospital and room environment, low bacterial diet are important. For this purpose, the aim of this questionnaire study was to assess the characteristics of hospital settings in Turkey.

\section{Materials and Methods}

A multicenter-descriptive questionnaire study was conducted on 36 centers which followed patients with hematological malignancies from different geografical locations of Turkey. These centers were university hospitals, tranining research hospitals and state hospitals. Because of the difference in infection risk and control measures, bone marrow transplantation units were excluded. Survey participation requests were questioned by telephone. Each center had been contacted at least for three-times till getting answer. Questionnaire was answered by two different doctors from each center. Questionnaire was answered within 5 days and reached by electronic mail or post(cargo). The questionnaire included questions on personal information (7 questions), demographic features, hospital and room characteristics (7 questions), service physical conditions (9 questions), presence of infection control committee, standart operation procedures for hospital cleaning applications, processes, and controls, isolation measures and hospital policies (41 questions), and it was formed as 64-questions and 13 pages.

\section{Results}

\section{Study Population and Characteristics}

Thirty-six centers including 20 (55.5\%) University Hospitals, 12 (33.3\%) Research Hospitals, 3 (8.3\%) State Hospitals and one Private University Hospital participated in this survey. The female to male ratio was 2.3: 1. Questionnaire responders' median age was 39.5 (min-max: 32-66) years. The participanting doctors were $88.8 \%$ (32/36) pediatric infection specialist, $5.5 \%$ $(2 / 36)$ pediatric hematology specialist and $2.7 \%(1 / 36)$ pediatricians in the centers.

\section{General Features of Hospitals for Pediatrics}

The number of beds in 33 (94.3\%) centers was 50 beds and over. Twenty-one $(58.3 \%)$ centers had a seperate pediatric infectious disease unit. Pediatric infectious disease units most frequently $(28.6 \%, 6 / 21)$ had $11-15$ beds in service. The median number of nurses in the pediatric infection units was 7 (minmax: 1-15). The median number of nurses per bed was 0.43 (min-max: 0.13-1.67) in PIU (Table I). All centers had infection control committee and provided training for infection prevention to patients and their hospital attendants.

\section{Room Features of Hospitals for Pediatrics}

The total count of single rooms were 143 in the participitating hospitals, and median was 2 (0-50) in 32 centers. The distribution and medians of bed numbers in a room of every center are shown in Table II. $66.6 \%$ (24/36) of the centers had toilet in all patients' room and $8(22.2 \%)$ centers in single rooms.

Table 1. The medians of total nurse number and at a night shift according to total bed number in the pediatric infectious disease units of centers

\begin{tabular}{|l|c|c|}
\hline & Total nurse number \\
Median (min-max) & $\begin{array}{c}\text { Nurse number at a night shift } \\
\text { Median (min-max) }\end{array}$ \\
\hline The interval of total bed number ( $n=$ center number) & & 1.00 \\
$\leq 5(n=1)$ & 5.00 & $0.5(0-1)$ \\
$6-10(n=2)$ & $1(1-1)$ & $1(1-2)$ \\
$11-15(n=6)$ & $6(2-7)$ & $2(1-6)$ \\
$16-20(n=5)$ & $8(7-10)$ & $1.5(1-2)$ \\
$21-25(n=2)$ & $7(4-10)$ & $2(2-2)$ \\
$26-30(n=3)$ & $11(11-15)$ & $2(2-2)$ \\
31 and up $(n=2)$ & $7.5(5-10)$ & \\
\hline \multicolumn{2}{|r}{} \\
\hline
\end{tabular}

Table 2. The distribution and medians of bed numbers in a room of the participants' centers

\begin{tabular}{|l|c|c|}
\hline & Center & $\begin{array}{c}\text { Bed number } \\
\text { The interval of Bed Number in a room }\end{array}$ \\
\hline Single bed $(n=143)$ & 32 & $2(0-50)$ \\
$2-3$ beds $(n=337)$ & 30 & $8.5(0-64)$ \\
$4-5$ beds $(n=24)$ & 32 & $0(0-8)$ \\
$6-8$ beds $(n=4)$ & 32 & $0(0-4)$ \\
\hline
\end{tabular}


There was anteroom in the patients' room in 11 centers. The door features of the patients' room included mostly $(94.1 \%$, 32/34) manually opened door, and there was no automatic or device operated room door in any centers. Room ventilation of six centers was only by directed airflow. Ten (27.7\%) out of the 36 centers had hepa filter system for clean room and five of them had negative pressure room.

Faucets of the patients'room were most fequently manual $(94.4 \%, 34 / 36)$. Hand hygiene products of the centers were alcohol hand antiseptic $(72.2 \%, 26 / 36)$, liquid soap (30.5\%, $11 / 36)$ and chlorhexidine gluconate $(16.6 \%, 6 / 36)$.

\section{Physical Conditions for Pediatric Neutropenic Fever Patients, Isolation and Precautions}

$25 \%(9 / 36)$ of the centers always followed pediatric neutropenic fever patients in a single room. Other centers might have admitted pediatric neutropenic fever patients in the same room with other patients. However, 21 centers noticed that they always considered the diagnosis of the roommate patient at admission process. Four centers declared that they admitted at least $50 \%$ and up of pediatric patients with neutropenia and fever have been followed up in rooms with hepa filter system.

The rooms of pediatric neutropenic patients were cleaned at least daily in all centers $73.5 \%$ (25/34) once a day, $20.6 \%$ (7/34) of the enters twice a day, $5.9 \%(2 / 34)$ of the centers three times a day. The cleaning agents for these rooms were mostly chlorine tablet $(58.3 \%, 21 / 36)$, detergent $(22.2 \%, 8 / 36)$ and rapid surface disinfectant $(47.2 \%, 17 / 36)$.

Patient-spesific stethoscope/sphygmomanometer was most frequently used (69.4\%) (25/36) only for high-risk patients. The frequency of cleaning duration of these equipments was once a day in 24 (66.6\%) centers, once a week in 6 (16.6\%) centers and at discharge in 2 (5.5\%) centers.

The rates of using protective equipments by the personnel: facemasks, gloves and gowns for pediatric neutropenic patients were $80.5 \%$ (29/36), 47.2\% (17/36) and 47.2\% (17/36), respectively.

Temperature was measured using tympanic $(54.5 \%$, $18 / 33)$, oral $(3 \%, 1 / 33)$, axillary $(42.4 \%, 14 / 33)$ in pediatric neutropenic patients but rectal way was not being prefered in any center $(0 \%, 0 / 33)$.

Thirteen $(38.2 \%, 13 / 34)$ centers prefered hickmann catheter for accessing a patient's central line. Training was performed for catheteter care in all centers (32/32, 4 missing) and catheter care was performed mostly by nurses $(75 \%, 24 / 32)$. Povidone iodine $(56.7 \%, 17 / 30)$ and chlorhexidine $(23.3 \%$, $7 / 30$ ) were used as an appropriate antiseptic agent in most.

There was an opportunity of cleaning neutropenic fever patients' personal laundry in home type washing machine in $55.5 \%(20 / 36)$ of the centers.

\section{Basic Oral Care}

Basic oral care was usually performed by nurses in most of the centers $(72.2 \%, 26 / 36)$ and with frequently used $0.5 \%$ sodium bicarbonate and $0.9 \%$ saline as oral rinses for neutropenic fever patients.

\section{Neutropenic Diet and Quality of Food}

The use of a low microbial diet or neutropenic diet for neutropenic fever patients was available in 27 of the 36 centers $(75 \%) .75 \%(27 / 35)$ of the centers had dieticians in the inpatient clinics of hospital.

Disposable plates were used in $27.3 \%(9 / 33)$ of the centers. It seemed that neutropenic fever patients $(5.5 \%, 2 / 36)$ rarely used tap water for drinking in centers.

\section{Visitor Restrictions and Hospital Policies for Toys and the Others}

Visitor restrictions were performed in all centers $(100 \%$, $36 / 36$ ). Visitors had to interview with healthcare staff before visit. None of the centers allowed plants or flowers in hospital rooms. Twenty-eight (77.7\%) centers would allow to keep toys in patient rooms with some restrictions. Sixteen (44.4\%) centers had hospital policy about keeping toys in patient rooms. Toys were cleaned daily in $51.9 \%(14 / 27)$ of the centers and mostly in patient room $(96.7 \%, 29 / 30)$.

\section{Discussion}

To date, the present study is the first one to assess the characteristics of hospital settings which follow up patients with hematological malignancies in Turkey. Questionnaire responses were received from different parts of Turkey. Major limitation of the study was the fact that most of the respondents were from centers employing pediatric infectious disease specialist (88.8\% 32/36), therefore, it is not mentioned if the pediatric infectious disease specialists who follow neutropenic fever patients are sufficient in these centers and if there is, in any way, some protocol for neutropenic patient.

The prevention and control of infection contributes to the improvement of the prognosis of patients with hematological malignancies. Physicians must be aware of infection risks and take precautions for infectious complications through the neutropenic period.

In this study, most of the responders used alcohol hand antiseptic, liquid soup and chlorhexidine gluconate for hand hygiene. Hand antisepsis reduces the incidence of health care associated infections. Health care associated pathogens can be transmitted not only from infected or draining wounds, but also from colonized areas of normal, intact patient skin (3-5).

As part of infection control and prevention program, all centers in this study had infection control committee which 
provided training for patients, their hospital attendant sand $\mathrm{HCW}$ to improve patient care activities.

There is a diverse number and type of microorganisms present on environmental surfaces. After physical removal, as recommended by guidelines, chlorine solutions, disinfectant/ detergent formulations and rapid acting surface disinfectant were used for environmental surface cleaning, and ethyl alcohol or isopropyl alcohol in concentrations of $60 \%-90 \%$ were used for medical equipment in the present study (e.g., stethoscopes and ventilators) (5).

In hematology departments, CVL are indispensable tools, allowing the administration of fluids, chemotherapy, antibiotics, blood products, parenteral nutrition and blood sampling. However, hematology patients who have CVL are at a very high risk of BSI. The optimal type of CVL (internal or external) is controversial. In most studies, centers currently favor ports over external CVLs due to a lower risk of infectious and thrombotic complications (6) In our questionnaire study, $38.2 \%$ of the patients had external CVLs placed. As CDC suggested, many centers in our study used $>0.5 \%$ chlorhexidine $(23.3 \%)$, povidone iodine $(56.7 \%)$ skin preparation with alcohol for the prevention of intravascular catheter-related infections.

Research evaluating potential benefits of a neutropenic diet in hematology patients is very limited, but the diet is still prescribed in many centers aiming to reduce infection risk. Low bacterial diet (LBD) can prevent foodborne infection and/or bacteremia and infection-related mortality in neutropenic patients, but much remains ambiguous (7). The results indicate that most of the institutions $(75 \%)$ in our study recommend a neutropenic diet .

Moist environments and aqueous solutions in health care settings have the risk of reservoirs for waterborne microorganisms. The most common reigons for waterborne infections in patient care areas are sinks, faucets, aerators, showers, and toilets. The technical characteristics of electronic faucet can lead to contamination, on the other hand, there was no further contamination of the conventional faucets. Nowadays, there is no definite recommendation for faucet in NP services. It is thought that faucets that open and close with pedals or elbows are useful $(8,9)$. In our study, the most widely used faucets were manuel.

Filtration, the physical removal of particulates from air, is the first step in cleaning the room air. Rooms for high-risk, immunocompromised patients should be designed to minimize fungal spores in the air by using high-efficiency particulate air (HEPA) filters (directed room air flow, positive room air pressure; well-sealed rooms; $\geq 12$ air changes per hour) (9).
Other than hematopoietic stem cell transplantation (HSCT) recipients, it is not necessary for single rooms to have HEPA filtration. Double doors of the room is recommended. In this sudy approximately one third of the centers contain HEPA filtration and double doors. While building new hospitals, this issue should be taken into account.

Fresh flowers, dried flowers, and potted plants are common substances in health care facilities. It is thought that plants are sources of bacteria and fungus. Health care associated outbreaks due to plants with invasive aspergillosis, fusarium and pseudomonas have pointed the importance of the risk among immunosuppressed patients (8). As implemented in all hospitals in this study, plants and dried or fresh flowers should not be allowed in the rooms of hospitalized neutropenic patients.

Bacteria and viruses are commonly colonized on toys and carry infections associated with respiratory and gastrointestinal illnesses. In a pediatric oncology unit, a nosocomial rotavirus outbreak occured due to playing with shared toys (10). An outbreak of Pseudomonas aeruginosa in a pediatric oncology ward has taken place because of water-retaining bath toys. Water-retaining bath toys and plush toys should not be used by immunocompromised patients. And also centers which follow immunsupressive patients should provide a written comprehensive policy for toys (11). In the present study, about half of the hospitals had a hospital policy for toys, and toys were cleaned daily and mostly in patient room.

In conclusion, prevention and control of infection contributes to the improvement of the prognosis of patients with hematological malignancies. Physicians must be aware of the infection risks and take precautions for infectious complications through the neutropenic period. There is no consistent guidance for environmental infection control for NP in Turkey. There are differences between centers. Standard protocols should be established and implemented for patients with hematological malignancies.

Ethics Committe Approval: Ethics committee approval is not received as it is a questionnaire study.

Informed Consent: Patient concent was obtained.

Peer-review: Externally peer-reviewed.

Author Contributions: Concept - ZGGA, AK, AB; Design - ZGGA, AK, $A B$; Supervision - AK; Materials - All of authors; Data Collection and/ or Processing - ZGGA, AK, AB; Analysis and/or Interpretation - ZGGA, $A K, A B$; Literature Review - ZGGA, AK, AB; Writing - ZGGA, AK, AB; Critical Review - All of authors.

Conflict of Interest: The authors declare no conflict of interest. Financial Disclosure: There is no financial support for the study. 


\section{References}

1. Fisher JL, Stanley K, Phillips M, Pham V, Klejmont LM. Preventing infections in children with cancer. Pediatr Rev 2016;37:247-57. [CrossRef],

2. Siegel JD, Rhinehart E, Jackson M, Chiarello L, the Health Care Infection Control Practices Advisory Committee. 2007 guideline for isolation precautions: preventing transmission of infectious agents in health care settings. https://www._cdc.gov/infectioncontrol/pdf/guidelines/isolation-guidelines.pdf [CrossRef],

3. Centers for Disease Control and Prevention. Guideline for hand hygiene in health-care settings recommendations of the Healthcare Infection Control Practices Advisory Committee and the HICPAC/SHEA/APIC/ IDSA Hand Hygiene Task Force. 2002;25: (No.RR-16):1-48. [CrossRef]

4. Larson EL, Cronquist AB, Whittier S, Lai L, Lyle CT, Della Latta P. Differences in skin flora between inpatients and chronically ill patients. Heart Lung 2000;29:298-305. [CrossRef].

5. Rutala WA. APIC guideline for selection and use of disinfectants. Am J Infect Control 1996;24:313-42. [CrossRef].

6. McLean TW, Fisher JC, Snively BM, Chauvenet AR. Central venous lines in children with lesser risk acute lymphoblastic leukemia: optimal type and timing of placement. J Clin Oncol 2005;23:3024-9.'[CrossRef]"

7. Fox N, Freifeld AG. The neutropenic diet reviewed: moving toward a safe food handling approach. Oncology 2012;26:572-5. [CrossRef]
8. Centers for Disease Control and Prevention. Guidelines for environmental infection control in health-care facilities: recommendations of CDC and the Healthcare Infection Control Practices Advisory Committee (HICPAC). MMWR 2003;52(No. RR-10):1-48. [CrossRef]

9. Merrer J, Girou E, Ducellier D, Clavreul N, Cizeau F, Legrand P, et al. Should electronic faucets be used in intensive care and hematology units? Intensive Care Med 2005;31:1715-8. [CrossRef].

10. Rogers M, Weinstock DM, Eagan J, Kiehn T, Armstrong D, Sepkowitz KA. Rotavirus outbreak on a pediatric oncology floor: possible association with toys. Am J Infect Control 2000;28:378-80. [CrossRef].

11. Tomblyn M, Chiller T, Einsele H, Gress R, Sepkowitz K, Storek J, et al. Center for International Blood and Marrow Research; National Marrow Donor program; European Blood and Marrow Transplant Group; American Society of Blood and Marrow Transplantation; Canadian Blood and Marrow Transplant Group; Infectious Diseases Society of America; Society for Healthcare Epidemiology of America; Association of Medical Microbiology and Infectious Disease Canada; Centers for Disease Control and Prevention. Guidelines for preventing infectious complications among hematopoietic cell transplantation recipients: a global perspective. Biol Blood Marrow Transplant 2009;15:1143-238. [CrossRef]: 